\title{
Pengembangan Sensor Kloramfenikol Berbasis Bovine Serum Albumin menggunakan Spektrofotometri UV (The Development of Chloramphenicol Sensor Based on Bovine Serum Albumin using Spectrophotometry UV)
}

\author{
Sarah Aisha, Bambang Kuswandi, Dwi Koko Pratoko \\ Fakultas Farmasi, Universitas Jember \\ Jln. Kalimantan 37, Jember 68121 \\ e-mail korespondensi: b_kuswandi.farmasi@unej.ac.id
}

\begin{abstract}
Misuse of antibiotics has been discovered in shrimp exported from Indonesia, one of them is chloramphenicol, therefore it is necessary to develop methods for chloramphenicol detection. In this study, the chemical sensor for chloramphenicol detection has been developed. The sensor developed by immobilized bovine serum albumin (BSA) onto cellulose acetate membrane. The sensor has linear range of 6-16 $\mu \mathrm{g} / \mathrm{ml}$ chloramphenicol with $r 0.999$ and limit of detection (LOD)-limit of quantification (LOQ) value of $0.74-2.21 \mu \mathrm{g} / \mathrm{ml}$. The $R S D$ value of repeatability and intermediet precision were $2.41 \%$ and $2.31 \%$, where the recovery was $100.29 \%$. Three of the five samples of tiger shrimp on the market containing chloramphenicol at level of 1.03; 2.48; and $3 \mu \mathrm{g} / \mathrm{ml}$. The result also shown in good agreement with conventional spectrophotometry UV-Vis method.
\end{abstract}

Keywords: shrimp, chloramphenicol, BSA, cellulose acetate

\begin{abstract}
Abstrak
Penyalahgunaan antibiotika telah ditemukan pada udang yang di ekspor dari Indonesia, salah satunya adalah kloramfenikol, untuk itu perlu dikembangkan metode analisis kloramfenikol. Pada penelitian ini telah dikembangkan sensor kimia untuk deteksi kloramfenikol. Sensor ini dikembangkan dengan mengimobilisasi Bovine Serum Albumin (BSA) pada selulosa asetat. Studi ini mengukur lineritas konsentrasi 6-16 $\mu \mathrm{g} / \mathrm{ml}$ dengan $r$ 0,999 dan nilai batas deteksi-batas kuantifikasi $0,74-2,21$. Nilai RSD dari presisi repeatabilitas dan intermediet sebesar $2,41 \%$ dan $2,31 \%$, serta nilai recovery dari uji akurasi sebesar $100,29 \%$. Tiga dari lima sampel udang windu di pasaran mengandung kloramfenikol dengan kadar 1,03; 2,48; dan $3 \mu \mathrm{g} / \mathrm{ml}$. Hasilnya juga berkesuaian dengan metode spektrofotometri UV-Vis konvensional.
\end{abstract}

Kata kunci: udang windu, kloramfenikol, BSA, selulosa asetat

\section{Pendahuluan}

Budidaya udang telah banyak dikembangkan di Indonesia. Banyaknya kendala yang harus dihadapi para petambak seperti penyakit pada udang baik karena bakteri, virus maupun jamur yang dapat menimbulkan kematian sehingga menurunkan tingkat produksi, membuat budidaya udang tidak mudah untuk dilakukan [1]. Dalam rangka mengendalikan penyakit udang terutama yang disebabkan oleh bakteri, maka petambak seringkali menggunakan antibiotik terutama kloramfenikol [2].

Kloramfenikol merupakan suatu golongan antibiotik yang menghambat pertumbuhan bakteri (bakteriostatik), tetapi dalam konsentrasi tinggi terkadang dapat juga bersifat bakterisidal [3]. Kloramfenikol termasuk salah satu dari sembilan jenis bahan tambahan makanan yang dilarang di Indonesia [4]. Masih ditemukannya kasus penggunaan kloramfenikol terutama pada produk udang tambak membuat analisis kloramfenikol menjadi sangat penting. Analisis 
kloramfenikol banyak dilakukan dengan metode LC/MS [5], KLT [6] serta spektrofotometri UV-Vis [7] namun perlu dikembangkan metode yang lebih mudah, praktis, dan murah. Pada penelitian ini dikembangkan sensor kloramfenikol berbasis BSA menggunakan spektrofotometri UV.

Sensor yang digunakan merupakan selulosa asetat yang terimobilisasi BSA. Selulosa asetat sendiri berasal dari klise film yang telah dibersihkan dari bahan pembawa lainnya dengan asam kuat kemudian direndam dalam larutan BSA. BSA sendiri banyak digunakan sebagai protein pembawa untuk mengikat antibiotik.

\section{Metode Penelitian}

Jenis penelitian yang dilakukan adalah experimental laboratories di Laboratorium Bio dan Kemosensor Bagian Kimia Farmasi mulai bulan Januari 2016 hingga Juli 2016.

Alat-alat yang digunakan dalam penelitian ini adalah spektrofotometer UV-Vis (Hitachi U1800), sentrifugasi (Hermle), timbangan analitik (OHAUS PAA214), pH meter (Denver).

Bahan-bahan yang digunakan dalam penelitian ini adalah BSA (Merck), kloramfenikol base, trisodium sitrat (Bratako Chemika), akuades, etanol $96 \%, \mathrm{HCl} 2 \mathrm{~N}, \mathrm{HCl} 4 \mathrm{~N}, \mathrm{NaOH}$, klise film, eritromisin, pakan udang, dan sampel udang windu yang berasal dari PT Taching Windu Jaya di Situbondo.

Penelitian dilakukan dengan tahapan fabrikasi selulosa asetat, optimasi selulosa asetat yang sudah diimobilisasi BSA (sensor), karakterisasi sensor meliputi linieritas, batas deteksi, batas kuantifikasi, selektivitas, presisi dan akurasi, kemudian aplikasi pada sampel.

\section{Fabrikasi Selulosa Asetat}

Pembuatan atau fabrikasi sensor berasal dari klise film yang direndam dalam $\mathrm{HCl} 4 \mathrm{~N}$ kemudian dicuci dengan aquadest dan dipotong sesuai ukuran kuvet. Selulosa asetat kemudian direndam dalam larutan BSA $1.000 \mu \mathrm{g} / \mathrm{ml}$ selama 24 jam.

\section{Preparasi Sampel}

Sampel udang windu dibersihkan dan dihaluskan kemudian ditimbang 3 gram. Sampel dimasukkan tabung sentrifugasi, ditambah $6 \mathrm{ml}$ etanol dan disentrifugasi selama 5 menit dengan kecepatan $4.000 \mathrm{rpm}$. Filtrat yang dperoleh dimasukkan labu ukur $10 \mathrm{ml}$ dan ditambahkan tris $\mathrm{HCl} \mathrm{pH} 7$ sampai tanda.

\section{Hasil Penelitian}

Kondisi optimum yang didapat yaitu panjang gelombang maksimum $278 \mathrm{~nm}, \mathrm{pH}$ tris $\mathrm{HCl} \mathrm{7,} \mathrm{konsentrasi} \mathrm{BSA} 1.000 \mu \mathrm{g} / \mathrm{ml}$ dan waktu perendaman 24 jam seperti terlihat pada Gambar 1-Gambar 4.

Gambar 1 menunjukkan hasil dari penentuan panjang gelombang maksimum dari larutan kloramfenikol yang diukur absorbansinya pada 200-400 nm. Panjang gelombang maksimum terletak pada $278 \mathrm{~nm}$ dengan absorbansi terbesar yaitu 0,306. Panjang gelombang tersebut yang digunakan pada penelitian ini.

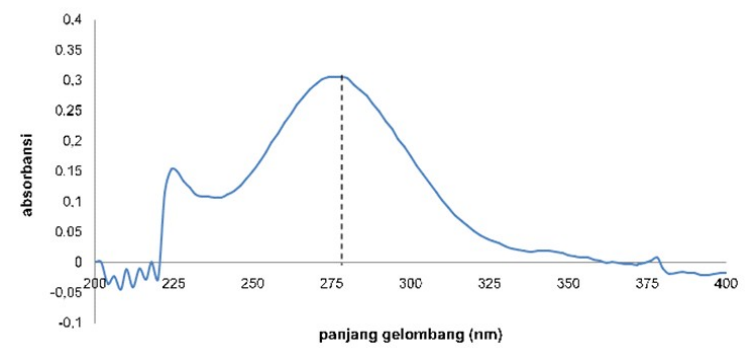

Gambar 1. Kurva penentuan panjang gelombang maksimum larutan kloramfenikol

Penentuan $\mathrm{pH}$ optimum dilihat dari nilai $\mathrm{r}$ dan slope yang diberikan. Gambar 2 menunjukkan kurva absorbansi kloramfenikol dengan pelarut pada berbagai $\mathrm{pH}$. Pada $\mathrm{pH} \mathrm{7,0}$ memberikan nilai $r$ 0,999 dan slope 0,015.

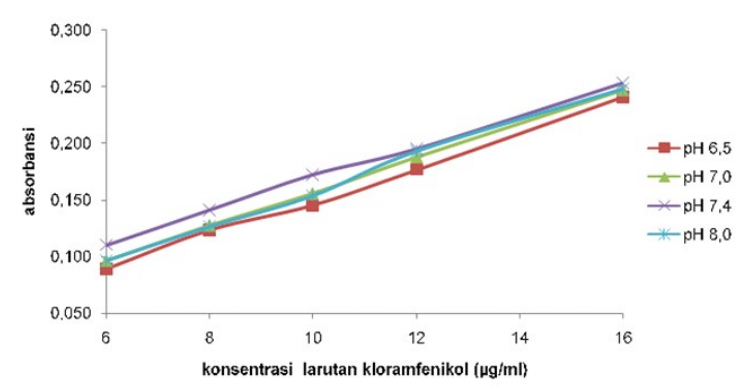

Pada Gambar 3 menunjukkan kurva absorbansi dari larutan kloramfenikol dengan BSA berbagai konsentrasi. Konsentrasi BSA yang memberikan $r$ mendekati 1 yaitu sebesar 0,998 dan slope terbesar yaitu 0,027 adalah konsentrasi $1.000 \mu \mathrm{g} / \mathrm{ml}$. Pada konsentrasi tersebut juga memberikan nilai serapan yang besar yaitu 0,2. 


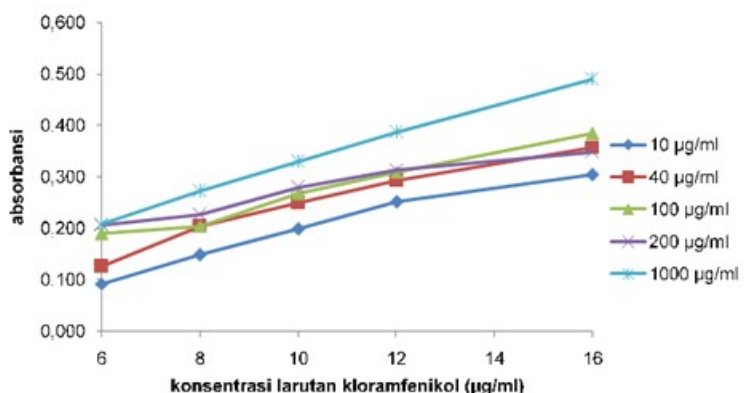

Gambar 3. Kurva konsentrasi larutan kloramfenikol dengan beberapa campuran BSA terhadap absorbansi

Waktu imobilisasi merupakan lamanya perendaman selulosa asetat pada larutan BSA sehingga BSA terimobilisasi pada media yaitu selulosa asetat. Waktu optimum yaitu 24 jam yang memberikan $\mathrm{r} 0,999$ dan slope 0,054 serta serapan terbesar 0,4 seperti ditunjukkan pada Gambar 4.

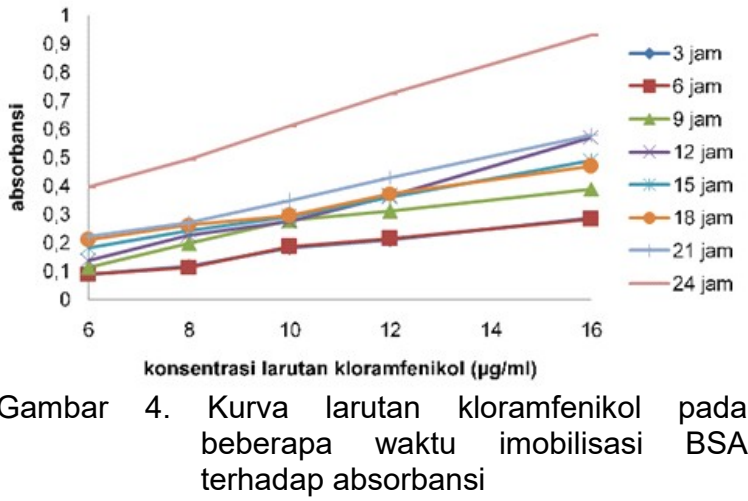

Karakteristik sensor meliputi linieritas dilakukan pada kloramfenikol konsentrasi 6,8 , 10, 12 dan $16 \mu \mathrm{g} / \mathrm{ml}$ seperti terlihat pada Gambar 5. Diperoleh nilai koefisien korelasi 0,999 dengan nilai $\vee \times 0$ 0,8954\% dan Xp 0,7458.

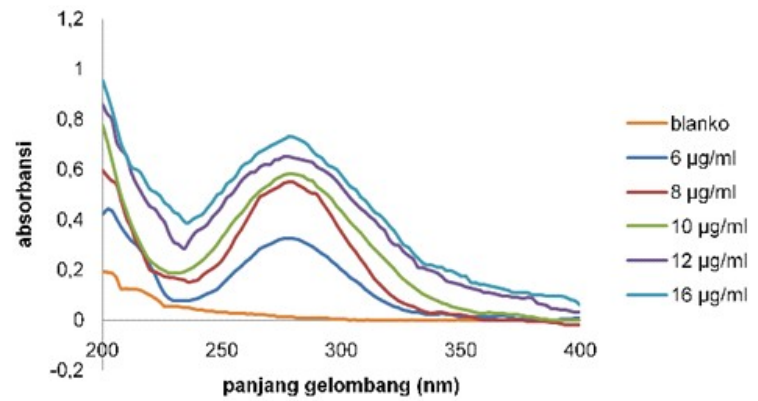

Gambar 5. Spektra larutan kloramfenikol berbagai konsentrasi

Batas deteksi dan batas kuantifikasi dari konsentrasi kloramfenikol 1, 2, 3, 4 dan $5 \mu \mathrm{g} / \mathrm{ml}$ yaitu sebesar 0,74 dan $2,21 \mu \mathrm{g} / \mathrm{ml}$. Gambar 5 menunjukkan spektra dari masing-masing konsentrasi yang juga memberikan $r$ 0,999.

Selektivitas kloramfenikol dinilai dari persen interferensi dengan adanya pengganggu eritromisin dan pakan ternak. Eritromisin digunakan sebagai pengganggu karena merupakan antibiotik yang juga sering digunakan petambak pada udangnya, sedangkan pakan ternak merupakan bahan yang sering diberikan bersamaan dengan kloramfenikol atau antibiotik lain. Interferensi yang melebihi batas yaitu pada pengganggu pakan ternak 100 dan $1.000 \mu \mathrm{g} / \mathrm{ml}$ seperti ditunjukkan pada Tabel 1.

Tabel 1. Interferensi eritromisin dan pakan ternak terhadap kloramfenikol

\begin{tabular}{clcc}
\hline No & Bahan $(\mu \mathrm{g} / \mathrm{ml})$ & Absorbansi Interferensi (\%) \\
\hline 1 & K 10 & 0,310 & \\
2 & K 10 + E 10 & 0,313 & 0,86 \\
3 & K 10 + E 100 & 0,317 & 2,15 \\
4 & K 10 + E 1.000 & 0,320 & 3,33 \\
5 & K 10 & 0,320 & \\
6 & K 10 + P 10 & 0,322 & 0,63 \\
7 & K 10 + P 100 & 0,339 & 6,15 \\
8 & K 10 + P 1.000 & 0,362 & 13.14 \\
\hline
\end{tabular}

k=kloramfenikol; e=eritromisin; $p=$ pakan ternak

Presisi yang dilakukan pada penelitian ini adalah repeatabilitas dan intermediet. Nilai simpangan baku relatif atau RSD yang dperoleh pada presisi repeatabilitas adalah $2,41 \%$ dan pada presisi intermediet adalah 2,31\%.

Karakteristik sensor yang terakhir adalah akurasi. Metode yang digunakan adalah metode adisi atau penambahan standar. Nilai rata-rata recovery dari penambahan standar 30\%, 45\% dan $60 \%$ adalah $100,29 \%$.

Aplikasi pada sampel udang windu di pasaran diperoleh hasil 3 dari 5 sampel mengandung kloramfenikol dengan kadar 1-3 $\mu \mathrm{g} / \mathrm{ml}$. Analisis kloramfenikol pada sampel menggunakan sensor dibandingkan dengan analisis menggunakan spektrofotometri UV dengan uji normalitas dan uji $t$ tidak berpasangan. Uji normalitas dan uji $t$ tidak berpasangan didapat nilai signifikansi $>0,05$.

\section{Pembahasan}

Hasil uji linieritas memperlihatkan hasil yang linier atau proporsional antara konsentrasi dan absorbansi yang ditunjukkan dengan nilai $r$ yang mendekati +1 atau -1 [8], dan nilai $\mathrm{V} \times 0$ $0,895 \%$ serta Xp 0,746 yang memenuhi kriteria penerimaan artinya kinerja metode yang 
digunakan untuk rentang konsentrasi yang diukur sangat baik.

Nilai batas deteksi yang diperoleh menunjukkan jumlah kloramfenikol terkecil yang masih dapat diukur spektrofotometer UV-Vis, yaitu sebesar $0,74 \mu \mathrm{g} / \mathrm{ml}$ sedangkan batas kuantifikasi menunjukkan konsentrasi terendah yang masih memenuhi kriteria presisi dan akurasi yaitu sebesar $2,21 \mu \mathrm{g} / \mathrm{ml}$.

Hasil uji selektivitas yaitu persen interferensi dari eritromisin pada ketiga konsentrasi tersebut masih dapat diterima yaitu $<5 \%$ [9]. Interferensi dari pengganggu pakan udang pada $10 \mu \mathrm{g} / \mathrm{ml}$ masih dapat diterima sedangkan pada konsentrasi 100 dan 1000 $\mu \mathrm{g} / \mathrm{ml}$ memberikan interferensi $>5 \%$ yang berarti bahwa pakan udang dapat mengganggu absorbansi kloramfenikol.

Pada uji presisi nilai RSD yang didapat telah memenuhi syarat penerimaan uji presisi untuk uji dengan kadar analit dalam matrik $0,001 \%$ yaitu sebesar $\leq 7,3 \%$ [8]. Hal tersebut menunjukkan bahwa metode analisis ini memberikan hasil yang presis atau seksama yang berarti kedekatan tiap hasil uji untuk melihat sebarannya adalah benar, dan dapat dikatakan metode ini memiliki ketelitian yang baik. Pada hasil uji akurasi yang menunjukkan recovery berada pada rentang penerimaan yaitu 90-107\% [8], maka dikatakan bahwa metode ini memiliki ketepatan yang baik dalam menunjukkan tingkat kesesuaian pengukuran dengan nilai yang sebenarnya.

Pengukuran terhadap sampel nyata didapat kadar kloramfenikol pada sampel 1,2 dan 3. Hasil dengan uji $t$ tidak berpasangan menunjukkan bahwa hasil pengukuran menggunakan sensor adalah benar atau tidak berbeda bermakna dengan hasil pengukuran menggunakan spektrofotometer UV-Vis.

\section{Simpulan dan Saran}

Sensor kloramfenikol dibuat dengan selulosa asetat yang terimobilisasi BSA 1.000 $\mu \mathrm{g} / \mathrm{ml} \mathrm{pH} 7$ selama 24 jam. Koefisien korelasi diperoleh 0,999 dengan batas deteksi 0,74 $\mu \mathrm{g} / \mathrm{ml}$, batas kuantifikasi $2,21 \mu \mathrm{g} / \mathrm{ml}$ dan metode yang presis serta akurat.

\begin{abstract}
Penelitian selanjutnya dapat dikembangkan metode validasi lain, pengaruh perubahan lain terhadap sensor, aplikasinya pada sampel lain dan modifikasi sensor untuk skala besar atau industri.
\end{abstract}

\section{Ucapan Terima Kasih}

Penulis mengucapkan terimasih kepada Chemo \& Biosensor Group Fakultas Farmasi Universitas Jember yang telah memberikan dukungan pendanaan dalam penyelesaian penelitian.

\section{Daftar Pustaka}

[1] Amri K. Budidaya udang windu secara intensif. Jakarta: PT Agromedia Pustaka; 2003.

[2] Soetomo, M. Teknik budidaya udang windu. Yogyakarta: Kansius. 2000.

[3] Katzung, BG. Basic \& clinical pharmacology. 10th ed. United States: Lange Medical Publications; 2007.

[4] Kementerian Kelautan dan Perikanan. Kelautan dan perikanan dalam angka 2014. Jakarta: Kementerian Kelautan dan Perikanan; 2014.

[5] Neuhaus B, Hurlbut J, Hammack W. LC/MS/MS analysis of chloramphenicol in shrimp. FDA/ORA/DFS. 2012; (4290): 1-8.

[6] Kucharska U, Leszczynska J. The use of elisa method for the determination of chloramphenicol in food products of animal origin. Chem Listy. 2000; 94: 190-194.

[7] Wafi A, Supriyanto G, Srie T. A novel spectrophotometric method for determination of chloramphenicol based on diazotization reaction at room temperature. JOCPR. 2015; 7(3): 272-277.

[8] Harmita. Petunjuk pelaksanaan validasi metode dan cara perhitungannya. MIK. 2004; 1(3): 117-135.

[9] Kuswandi, B. Sensor kimia teori, praktek, dan aplikasi. Jember: Jember University Press; 2010. 